\title{
PENGARUH EKSPOR, IMPOR DAN KURS TERHADAP CADANGAN DEVISA INDONESIA PERIODE TAHUN 2004 - 2018
}

\author{
Gentur Jalunggono ${ }^{*}$, Yulia Tri Cahyani ${ }^{1}$, Whinarko Juliprijanto ${ }^{1}$ \\ 1Jurusan Ekonomi Pembangunan, Fakultas Ekonomi, Universitas Tidar, Magelang, Indonesia \\ *Email corresponding author: jalunggono@untidar.ac.id
}

\begin{abstract}
Abstrak
Penelitian ini bertujuan untuk menganalisis pengaruh ekspor, impor dan kurs terhadap cadangan devisa Indonesia periode tahun 2004 - 2018. Variabel terikat yaitu cadangan devisa, dan yang menjadi variabel bebas yaitu ekspor, impor dan kurs. Penelitian ini menggunakan data sekunder dengan bentuk data time series yang diperoleh dari BPS (Badan Pusat Statistik) Indonesia. Analisis data yang digunakan yaitu uji asumsi klasik (uji normalitas, uji multikolineritas, uji heteroskedastisitas dan uji autokorelasi), regresi linear berganda dan uji statistik (uji koefisien determinasi $\left(\mathrm{R}^{2}\right)$, uji t dan uji F) dengan menggunakan aplikasi E-Views 10 sebagai alat analisis. Hasil analisis koefisien regresi secara parsial (uji t) menunjukkan ada pengaruh positif dan signifikan dari variabel ekspor dan variabel kurs terhadap variabel cadangan devisa, sedangkan variabel impor tidak memiliki pengaruh terhadap variabel cadangan devisa. Hasil analisis uji $\mathrm{F}$ menunjukkan ada pengaruh secara simultan atau bersama-sama dan signifikan dari variabel ekspor, impor dan kurs terhadap variabel cadangan devisa.
\end{abstract}

Kata Kunci: Ekspor, Impor, Cadangan Devisa

\begin{abstract}
This research aims to analyze the influence of exports, imports, and exchange rate on Indonesia's foreign exchange reserves in the period of 2004-2018. The dependent variable is foreign exchange reserves, whereas the independent variables consist of exports, imports, and exchange rate. The research uses secondary data in time series obtained from BPS (Central Bureau of Statistics). Data are analyzed with classical assumption tests (normality, multicollinearity, heteroscedasticity, and autocorrelation tests), multiple linear regression, and statistical tests (coefficient of datermination (R2), t-test, and F-test) using E-Views 10 application as an analysis tool. The result of the partial regression coefficient ( $t$-test) analysis indicates a positive and significant influence of export and exchange rate variables on foreign exchange reserves variable, while import variable has no influence on foreign exchange reserves variable. The F-test analysis results indicate a simultaneous and significant influence of exports, imports, and exchange rate on foreign exchange reserves.
\end{abstract}

Keywords: exports, imports, foreign exchange

\section{PENDAHULUAN \\ Latar Belakang Masalah}

Peningkatan output dari waktu ke waktu yang dapat dijadikan sebagai salah satu indikator penting untuk mengukur keberhasilan pembangunan suatu negara merupakan sebuah proses pertumbuhan ekonomi. Dalam kurun waktu lima belas tahun terakhir rata-rata pertumbuhan ekonomi Indonesia dikatakan cukup lambat yaitu sebesar 5,49 \%. Akan tetapi lambatnya pertumbuhan ekonomi diimbangi dengan tingginya tingkat impor, oleh karena itu Indonesia masih dikatakan sebagai negara berkembang. Walaupun dikategorikan sebagai negara berkembang, menurut Pundy dan Syamsurijal (2017) perkembangan pembangunan ekonomi Indonesia menunjukkan semakin terintegrasi dengan perekonomian dunia. Kondisi ini dapat terjadi karena dianutnya sistem perekonomian terbuka yang dalam aktivitasnya tidak lepas dari 
fenomena hubungan internasional seperti ekspor dan impor antara negara satu dengan negara lainnya.

Ekspor merupakan salah satu sumber cadangan devisa. Devisa akan berkurang jika tingkat impor lebih besar dibandingkan dengan tingkat ekspor. Semakin besar cadangan devisa di suatu negara maka negara tersebut mampu melakukan kegiatan perdagangan internasional dengan negara lain sehingga besar kecilnya akumulasi cadangan devisa suatu negara biasanya akan ditentukan oleh kegiatan perdagangan (ekspor dan impor) serta arus modal negara tersebut (Gandhi, $2006: 1-2$ ).

Indonesia menganut sistem devisa bebas dalam kebijakan devisanya yang berarti bahwa aliran modal bebas masuk dan keluar sehingga perekonomian negara akan rentan terhadap risiko yang muncul dari kegiatan spekulasi pemilik modal yang sewaktu-waktu dapat menarik dananya. Dengan ini maka kebijakan cadangan devisa di Indonesia diarahkan untuk dapat memelihara kondisi perekonomian yang sehat, mendorong ekspor, mengendalikan impor, serta mendukung kestabilan pasar dan kurs valuta asing (Putri, 2017). Realita saat ini di Indonesia cadangan devisa mengalami tren penurunan. Cadangan devisa yang menurun menganggu perekonomian negara karena cadangan devisa sangat berperan penting dalam perdagangan internasional. Penyusutan cadangan devisa di Indonesia selama tahun 2018 dapat dilihat pada grafik berikut :

Grafik 1.1 Penyusutan Cadangan Devisa Tahun 2018

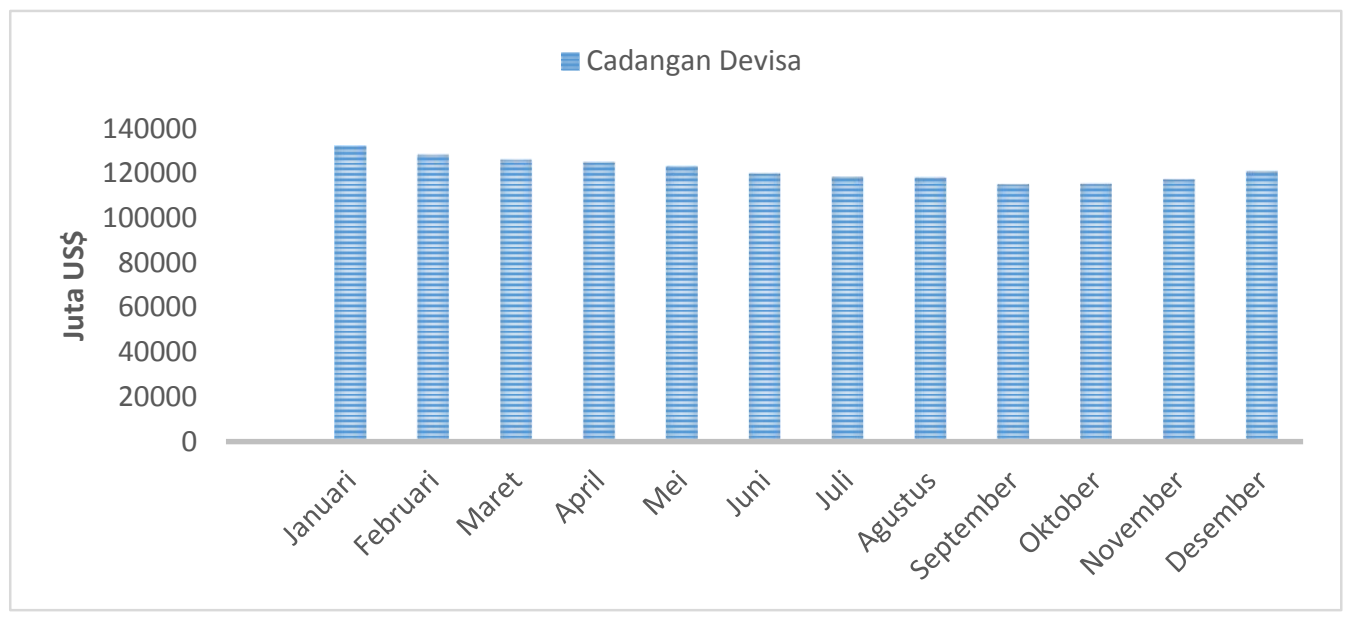

Sumber : Bank Indonesia, 2019 (Data Diolah)

Berdasarkan grafik 1.1 menunjukkan bahwa cadangan devisa mengalami tren penyusutan rata-rata senilai US\$ 2 milyar untuk setiap bulannya pada tahun 2018. Kondisi tersebut dikarenakan untuk membiayai pelunasan utang luar negeri pemerintah dan biaya impor yang tinggi. Jika suatu negara secara terus-menerus melakukan pinjaman luar negeri maka akan berdampak berkurangnya jumlah cadangan devisa. dengan menurunnya cadangan devisa Indonesia, menyebabkan lesunya perekonomian sehingga nilai tukar rupiah melemah. Penurunan devisa juga akan menyebabkan kegiatan impor yang tinggi untuk memenuhi kebutuhan dalam negeri. Namun ekspor akan semakin melemah karena tingkat produktivitasnya yang masih rendah.

Ekspor barang dan jasa merupakan salah satu sumber devisa utama yang mampu meningkatkan cadangan devisa negara. Ekspor memiliki hubungan yang erat dengan cadangan devisa. Maka dalam melakukan kegiatan ekspor, suatu negara akan memperoleh sejumlah uang 
dalam bentuk mata uang asing yang akan menjadi salah satu sumber pemasukan negara. Besarnya kegiatan ekspor Indonesia beberapa tahun dapat dilihat dari grafik berikut :

Grafik 1.2 Perkembangan Ekspor Indonesia Tahun 2004 - 2018

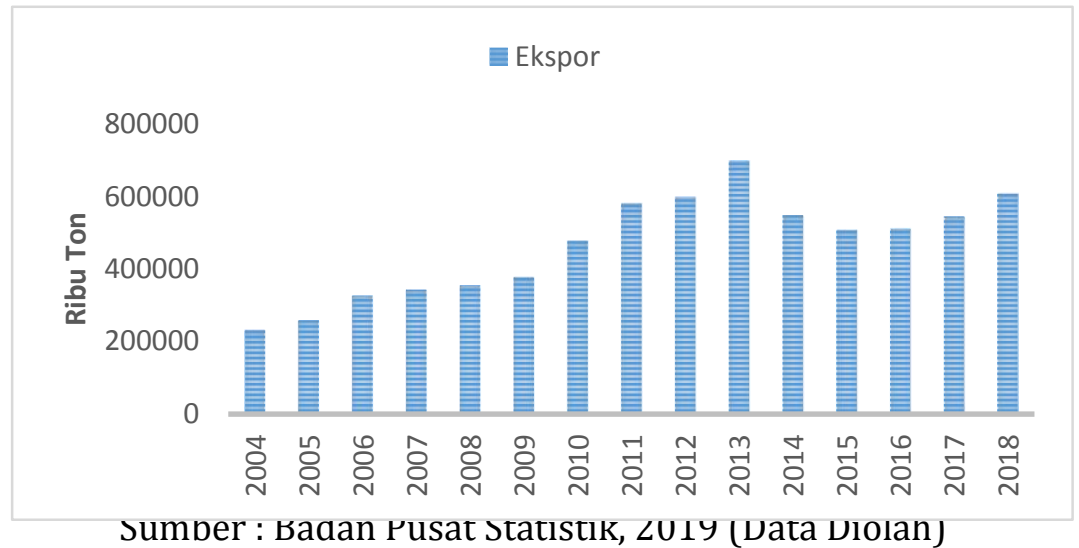

Berdasarkan grafik 1.2 menunjukkan bahwa terjadi tren peningkatan pada tingkat ekspor namun Bank Indonesia (2019) menyebutkan bahwa masih lemahnya kinerja ekspor karena penurunan harga komoditas. Lemahnya daya saing dan kebijakan struktural juga menjadi penyebabnya. Ekspor Indonesia didominasi oleh hasil pengolahan karena dianggap potensial sebagai salah atu sektor utama pendukung perekonomian negara dengan tingkat kontribusi yang tinggi. Negara tujuan utama ekspor Indonesia diantaranya Cina, Amerika Serikat, Jepang, India, Singapura.

Selain ekspor, Indonesia juga melakukan kegiatan impor untuk memenuhi kebutuhan yang tidak dapat diproduksi di dalam negeri. Menurut Sukirno (2013 : 203), impor adalah pembelian dan pemasukan barang dari luar negeri ke dalam suatu perekonomian. Kegiatan impor Indonesia nilainya cukup besar. Data impor di Indonesia dapat dilihat pada grafik berikut :

Grafik 1.3 Perkembangan Impor Indonesia Tahun 2004 - 2018

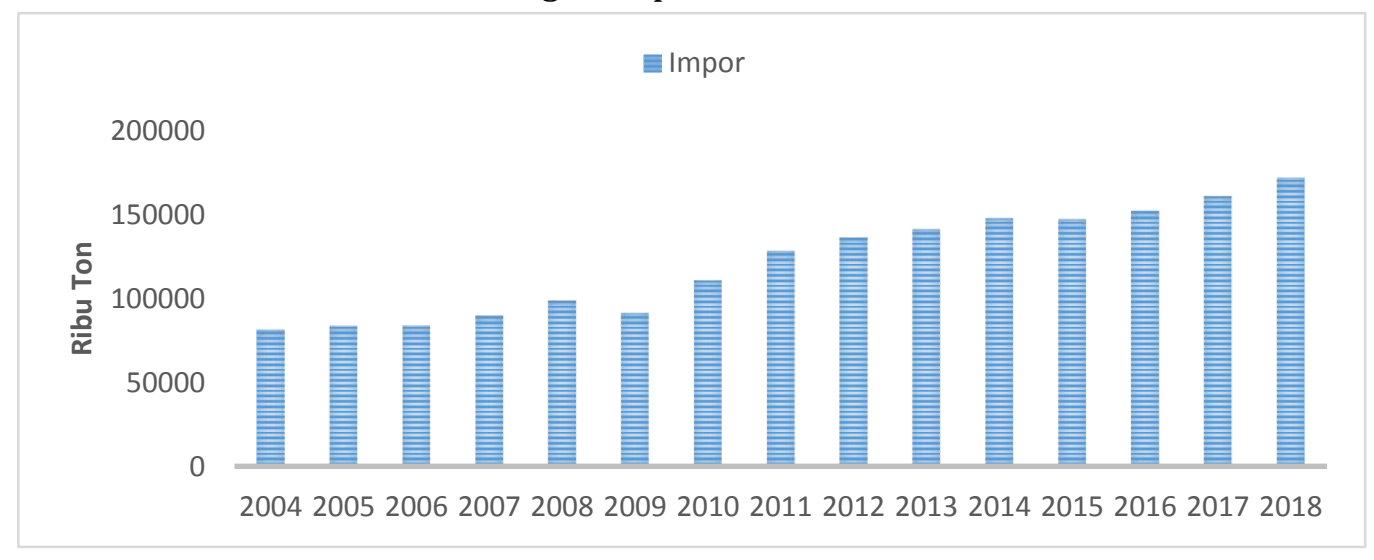

Sumber : Badan Pusat Statistik,2019 (Data Diolah)

Berdasarkan grafik 1.3 memperlihatkan bahwa impor cenderung semakin meningkat. Kondisi tersebut dikarenakan banyaknya barang modal dan barang baku yang masuk untuk pembangunan serta barang kebutuhan sehari-hari. Menurut Badan Pusat Statistik (BPS : 2017) komoditas terbesar yang diimpor di Indonesia berupa kebutuhan pangan seperti beras, jagung, gandum, meisilin, gula pasir, daging (ayam dan sapi), dan garam. Dengan tingginya tingkat 
kegiatan impor maka mampu mengurangi cadangan devisa karena negara membayar impor yang dilakukan menggunakan cadangan devisa yang dimiliki. Cadangan devisa dikatakan aman apabila mampu mencukupi kebutuhan impor untuk jangka waktu sekurang-kurangnya 3 bulan (Kuswantoro, 2017). Negara yang menjadi sumber adanya barang Impor di Indonesia adalah Cina, Thailand, Amerika Serikat, Singapura, Korea Selatan, Malaysia, Australia, India, Jerman.

Hubungan perdagangan internasional akan berhubungan dengan nilai tukar rupiah. Nilai tukar mata uang atau kurs dapat didefinisikan sebagai jumlah uang domestik yang diperlukan untuk membeli satu unit mata uang asing tertentu (Sukirno, 2013 : 21). Jika ekspor mengalami peningkatan maka akan terjadi kenaikan pada nilai tukar uang domestik sehingga menyebabkan pertambahan pada cadangan devisa. Sebaliknya, jika impor mengalami kenaikan maka nilai tukar uang domestik akan mengalami penurunan sehingga mampu mengurangi cadangan devisa. Perkembangan nilai tukar rupiah terhadap dolar dapat dilihat pada grafik berikut :

Grafik 1.4 Perkembangan Nilai Tukar Rupiah Tahun2004 - 2018

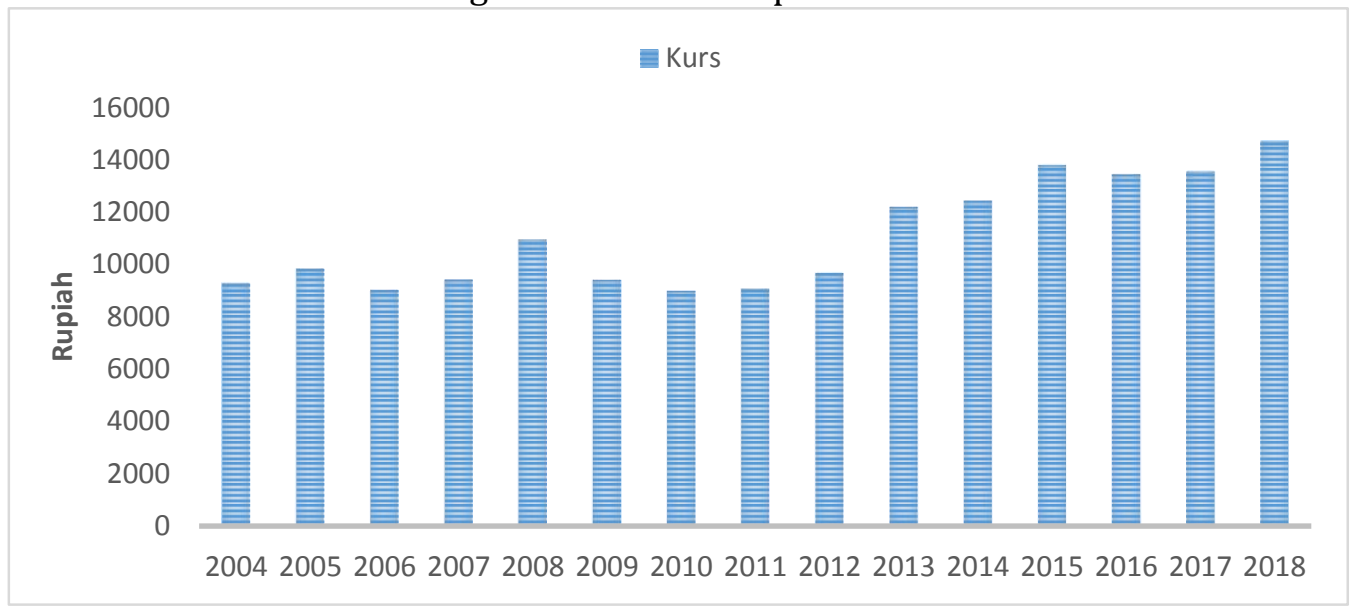

Sumber : Badan Pusat Statistik,2019 (Data Diolah)

Grafik 1.4 diatas menunjukkan bahwa terjadi tren kenaikan pada kurs sehingga menyebabkan nilai tukar rupiah terdepresiasi. Dengan terdepresiasinya nilai tukar rupiah berarti bahwa melemahnya nilai tukar rupiah terhadap mata uang asing, sehingg membutuhkan lebih banyak devisa untuk dapat bertransaksi dalam perdagangan internasional.

Secara umum dapat dilihat bahwa Ekspor di Indonesia selama periode 2004 - 2018 dalam keadaan yang meningkat namun cenderung lambat karena terdapat beberapa hambatan seperti kebijakan struktural dan daya saing. Impor di Indonesia selama periode 2004 - 2018 masih tinggi yang yang dapat berupa barang kebutuhan sehari-hari. Nilai tukar rupiah Indonesia selama periode 2004 - 2018 dalam keadaan yang fluktuatif namun cenderung menurun sehingga menyebabkan melemahnya nilai mata uang domestik dibanding dengan mata uang asing. Cadangan devisa Indonesia selama tahun 2018 menunjukkan tren yang menurun karena pertumbuhan impor yang lebih besar daripada ekspor. Berdasarkan pemaparan dan data yang telah disampaikan, maka penulis tertarik untuk melakukan penelitian dengan judul "Pengaruh Ekspor, Impor Dan Kurs Terhadap Cadangan Devisa Periode Tahun 2004 - 2018”

Penelitian ini bertujuan untuk Menganalisis pengaruh ekspor terhadap cadangan devisa Indonesia selama tahun 2004 - 2018, menganalisis pengaruh impor terhadap cadangan devisa Indonesia selama tahun 2004 - 2018, menganalisis pengaruh nilai tukar rupiah terhadap cadangan devisa Indonesia selama tahun 2004 - 2018, serta menganalisis pengaruh ekspor, 
impor dan nilai tukar secara bersama-sama terhadap cadangan devisa Indonesia selama tahun $2004-2018$.

\section{LANDASAN TEORI}

\section{Teori Hubungan Antar Variabel}

\section{Cadangan Devisa dengan Ekspor}

Dalam kegiatan ekspor maka akan mampu meningkatkan arus perdagangan baik berupa barang atau uang serta modal antar negara, dimana akan menciptakan hubungan ekonomi antar negara yang saling berkaitan (Tri Wibowo dan Hidayat Amir, 2005). Menurut Manurung (2016 : 33) salah satu faktor penting terjadinya peningkatan cadangan devisa adalah karena terjadinya peningkatan ekspor. Ekspor yang meningkat akan berdampak pula pada peningkatan cadangan devisa. Kenaikan ekspor suatu negara akan terjadi apabila kualitas dari barang ekspor mengalami kenaikan dan permintaan akan barang tersebut. Sesuai dengan penelitian yang dilakukan oleh Agustina dan Reny (2014) yaitu ekspor berpengaruh positif dan signifikan terhadap cadangan devisa. Jadi ekspor memiliki hubungan yang positif terhadap cadangan devisa.

\section{Cadangan Devisa dengan Impor}

Impor merupakan bagian penting dari perdagangan internasional. Besarnya impor dipengaruhi oleh banyaknya permintaan barang untuk memenuhi kebutuhan masyarakat (Jimmy Benny, 2013). Menurut Manurung (2016 : 54) impor merupakan faktor yang bisa mengurangi jumlah cadangan devisa. Impor perlu diturunkan mengingat terlalu banyak impor akan mengurangi jumlah cadangan devisa akibat membayar impor yang dilakukan. Tingginya tingkat impor maka akan mengurangi jumlah cadangan devisa suatu negara. Sesuai dengan penelitian yang dilakukan oleh Jimmy Benny (2013) yaitu impor berpengaruh negatif dan signifikan terhadap cadangan devisa. Jadi impor memiliki hubungan yang negatif terhadap cadangan devisa.

\section{Cadangan Devisa dengan Kurs}

Nilai tukar mata uang sangat berguna bagi negara karena digunakan sebagai satuan alat pembayaran pada saat melakukan transaksi internasional. Menurut Manurung (2016:57) ketika cadangan devisa mengalami perbaikan, maka akan muncul nilai tukar terhadap mata uang asing yang mengalami penurunan sehingga nilai tukar uang domestik menguat karena mampu memberikan stimulus untuk membuat nilai tukar mengalami apresiasi. Dengan semakin tingginya nilai tukar mata uang domestik, menunjukkan semakin kuatnya perekonomian negara yang bersangkutan, sehingga dapat memperoleh lebih banyak devisa. Sesuai dengan penelitian yang dilakukan oleh M. Kuswantoro (2017) yaitu kurs berpengaruh negatif dan signifikan terhadap cadangan devisa. Jadi, kurs memiliki hubungan yang negatif terhadap cadangan devisa.

\section{Kerangka Teoritis}

Berdasarkan kajian teoritis dan penelitian sebelumnya, maka tersusun kerangka teoritis untuk menguji hipotesis dari penelitian ini. Berikut kerangka teoritis dalam penelitian ini, yaitu :

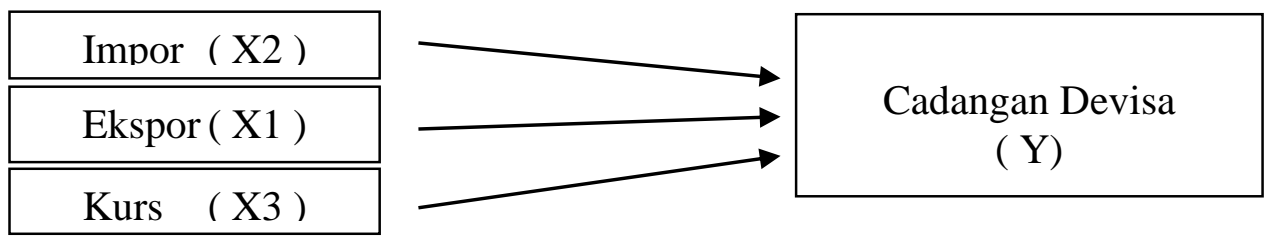

Gambar 2.1 Kerangka Teoritis Penelitian 


\section{METODE PENELITIAN}

\section{Desain Penelitian}

Penelitian ini menggunakan pendekatan deskriptif kuantitatif untuk menganalisis dengan intepretasi yang tepat, dan untuk menguji hipotesis-hipotesis.

\section{Variabel Penelitian}

Dalam peneltian ini yang menjadi variabel dependen adalah Cadangan Devisa (Y). Sedangkan yang menjadi variabel independen adalah Ekspor (X1), Impor (X2) dan Kurs atau Nilai Tukar (X3).

\section{Teknik Pengumpulan Data}

Teknik pengumpulan data yang digunakan dalam penelitian ini adalah dengan menggunakan cara observasi dan metode dokumentasi. Dari data yang dikumpulkan akan dikelompokkan berdasarkan tahun. Sehingga bentuk data berupa tabulasi yang menggunakan data time series dalam kurun waktu selama lima belas tahun (2004 - 2018) yang berisi mengenai cadangan devisa, ekspor, impor serta nilai tukar di Indonesia.

\section{Teknik Analisis Data}

\section{Uji Asumsi Klasik}

Pengujian terhadap asumsi klasik bertujuan untuk menghasilkan estimasi yang BLUE (Best Linier Unbiased Estimator) yaitu penaksiran yang linear, tidak bias dan mempunyai varian yang minimum (Gujarati, 2015 : 92). Uji ini meliputi uji normalitas, uji multikolineritas, uji heteroskedastisitas dan uji autokorelasi.

\section{Analisis Regresi Linear Berganda (Multiple Regression)}

Penelitian ini digunakan teknik analisis regresi linear berganda dengan menggunakan metode OLS (Ordinary Least Square) yang menggunakan alat analisis E-views 10 untuk menganalisis data. Analisis regresi linear berganda dalam penelitian ini digunakan untuk mengetahui pengaruh variabel independen yang dalam penelitian ini dijelaskan melalui variabel ekspor, impor dan kurs terhadap variabel dependen yaitu cadangan devisa Indonesia. Dari penjelasan tersebut dapat dirumuskan model sebagai berikut:

\section{Keterangan :}

$$
Y=\alpha+\beta_{1} X_{1}+\beta_{2} X_{2}+\beta_{3} X_{3}+e
$$

$$
\begin{array}{ll}
\mathrm{Y} & \text { : cadangan devisa } \\
\alpha & : \text { konstanta } \\
X_{1} & : \text { ekspor } \\
X_{2} & : \text { impor } \\
X_{3} & : \text { kurs } \\
\beta_{1} \beta_{2} \beta_{3} & : \text { koefisien regresi } \\
e & : \text { error }
\end{array}
$$

\section{UJI STATISTIK}

Secara statistik, ketepatan fungsi regresi dalam menaksir nilai aktual dapat diukur dari koefisien determinasi $\left(\mathrm{R}^{2}\right)$, nilai statistik $\mathrm{F}$ dan nilai statistik $\mathrm{t}$. 


\section{HASIL PENELITIAN DAN PEMBAHASAN}

Uji Normalitas

Tabel 4.1 Hasil Uji Normalitas

\begin{tabular}{lc}
\hline \hline Jarque-Bera & 0.305795 \\
Probability & 0.858217 \\
\hline
\end{tabular}

Sumber : E-Views 10, 2019 (Data Diolah)

Dari tabel 4.1 dapat dilihat bahwa nilai probabilitas Jarque-Bera sebesar 0,858217 yang lebih besar dari tingkat signifikansi yang digunakan $(\alpha=5 \%$ atau 0,05$)$ berarti dapat disimpulkan bahwa data model regresi pada penelitian ini berdistribusi normal.

Uji Multikolineritas

Tabel Hasil 4.2 Uji Multikolineritas

\begin{tabular}{ccc}
\hline \hline Variable & Centered & Keterangan \\
& VIF & \\
$\mathrm{C}$ & $\mathrm{NA}$ & \\
$\mathrm{X} 1$ & 1.203832 & Tidak Terdapat Multikolineritas \\
$\mathrm{X} 2$ & 1.018226 & Tidak Terdapat Multikolineritas \\
$\mathrm{X} 3$ & 1.213974 & Tidak Terdapat Multikolineritas \\
\hline \hline
\end{tabular}

Sumber : E-Views 10, 2019 (Data Diolah)

Dari tabel 4.2 diatas dapat dilihat bahwa dalam model penelitian ini tidak terjadi masalah multikolineritas karena nilai Variance Inflation Factor (VIF) masing-masing variabel independen kurang dari 10.

\section{Uji Heteroskedastisitas}

Tabel 4.3 Hasil Uji Heteroskedastisitas

\begin{tabular}{ll}
\hline \hline Prob. F(3,11) & 0.5125 \\
Prob. Chi-Square(3) & 0.4360 \\
Prob. Chi-Square(3) & 0.5696 \\
\hline \hline
\end{tabular}

Sumber : E-Views 10, 2019 (Data Diolah)

Dari tabel 4.3 diatas dapat dilihat bahwa hasil uji heteroskedastiditas dengan uji Glejser menunjukkan bahwa nilai probabilitas Chi-Square yaitu 0,4360 yang lebih besar dari tingkat signifikansi yang digunakan ( $\alpha=5 \%$ atau 0,05$)$, berarti dapat disimpulkan bahwa model regresi ini tidak terdapat masalah heteroskedastisitasi.

\section{Uji Autokorelasi}

Tabel 4.4 Hasil Uji Autokorelasi

Prob. F(2,9)

Prob. Chi-Square(2)

Sumber : E-Views 10, 2019 (Data Diolah)

Dari tabel 4.4 diatas dapat dilihat bahwa nilai probabilitas Chi-Square yaitu 0,7425 yang lebih besar dari tingkat signifikansi yang digunakan ( $\alpha=5 \%$ atau 0,05$)$, berarti dapat disimpulkan bahwa model regresi ini tidak terdapat gejala autokorelasi.

\section{Analisis Persamaan Regresi Linear Berganda}

Berdasarkan perhitungan menggunakan E-views 10, maka diperoleh persamaan sebagai berikut :

$Y=-67208,85+6,361566 X_{1}+0,72547 X_{2}+5,485924 X_{3}+e$

Dari hasil estimasi tersebut maka dapat diintepretasikan sebagai berikut :

1. Nilai dari konstanta sebesar - 67208,85 berarti dengan adanya pengaruh dari variabel independen yaitu ekspor, impor dan kurs yang dianggap nol, maka nilai dari variabel dependen yaitu cadangan devisa nilainya sebesar US\$ 67.208,85 juta. 
2. Koefisien regresi variabel ekspor terhadap cadangan devisa adalah positif dengan nilai koefisien sebesar 6,361566 berarti apabila nilai variabel rata-rata jumlah ekspor meningkat sebesar US\$ 1 juta maka cadangan devisa rata-rata akan meningkat sebesar US\$ 6,361566 juta. Dengan asumsi variabel ekspor tidak mengalami perubahan atau konstan.

3. Koefisien regresi variabel impor terhadap cadangan devisa adalah positif dengan nilai koefisien sebesar 0,072547 berarti apabila nilai variabel rata-rata jumlah impor meningkat sebesar US\$ 1 juta maka cadangan devisa rata-rata akan meningkat sebesar US\$ 0,072547 juta. Dengan asumsi variabel impor tidak mengalami perubahan atau konstan.

4. Koefisien regresi variabel kurs terhadap cadangan devisa adalah positif dengan nilai koefisien sebesar 5,485924 berarti apabila nilai variabel rata-rata jumlah kurs meningkat sebesar US\$ 1 juta maka cadangan devisa rata-rata akan meningkat sebesar US\$ 5,485924 juta. Dengan asumsi variabel kurs tidak mengalami perubahan atau konstan.

\section{Uji Statistik}

\section{Uji Koefisien Deretminasi $\left(R^{2}\right)$}

Tabel 4.5 Hasil Perhitungan nilai Adjusted $\left(\boldsymbol{R}^{2}\right)$

\begin{tabular}{ll} 
R-squared & 0.913515 \\
Adjusted R-squared & 0.889929 \\
S.E. of regression & 11260.89 \\
Sum squared resid & $1.39 \mathrm{E}+09$ \\
Log likelihood & -1.588 .943 \\
F-statistic & 3.873 .010 \\
Prob(F-statistic) & 0.000004 \\
\hline
\end{tabular}

Sumber : E-Views 10, 2019 (Dat Diolah)

Dari tabel 4.5 diatas diperoleh hasil estimasi regresi yaitu nilai Adjusted $\mathrm{R}^{2}$ sebesar 0,889929 yang berarti bahwa cadangan devisa di Indonesia dapat dijelaskan oleh variasi variabel ekspor, impor dan kirs sebesar 88,99 \% dan sisanya 11,01\% dijelaskan oleh variabel di luar model tersebut.

\section{Uji Signifikan Parameter Individual (Uji t)}

Tabel 4.6 Hasil Perhitungan Uji t

\begin{tabular}{cccc}
\hline \hline Variable & t-Statistic & Prob. & t-tabel \\
\hline $\mathrm{C}$ & -3.883307 & 0.0025 & \\
$\mathrm{X} 1$ & 7.902457 & 0.0000 & 1,796 \\
$\mathrm{X} 2$ & 0.530024 & 0.0666 & 1,796 \\
$\mathrm{X} 3$ & 3.432451 & 0.0056 & 1,796 \\
\hline \hline
\end{tabular}

Sumber : E-Views 10, 2019 (Data Diolah)

Dari tabel maka dapat diperoleh hasil sebagai berikut :

1. Pengaruh Ekspor pada Cadangan Devisa. Dari hasil uji parsial diperoleh nilai t-hitung sebesar 7,902457 sehingga diperoleh hasil t-hitung > t-tabel yaitu sebesar 7,902457 > 1,796 dengan nilai probabilitas sebesar $0,0000<$ taraf signifikansi yang digunakan yaitu 0,05 maka dapat disimpulkan bahwa Ho ditolak dan Ha diterima atau dapat diartikan bahwa variabel ekspor mempunyai pengaruh positif dan signifikan terhadap variabel cadangan devisa.

2. Pengaruh Impor pada Cadangan Devisa. Dari hasil uji parsial diperoleh nilai t-hitung sebesar 0,530024 sehingga diperoleh hasil $\mathrm{t}$-hitung $<\mathrm{t}$-tabel yaitu sebesar $0,530024<1,796$ dengan nilai probabilitas sebesar 0,0666 > taraf signifikansi yang digunakan yaitu 0,05 maka dapat 
disimpulkan bahwa Ho diterima dan Ha ditolak atau dapat diartikan bahwa tidak ada pengaruh dari variabel impor terhadap variabel cadangan devisa.

3. Pengaruh Kurs pada Cadangan Devisa. Dari hasil uji parsial diperoleh nilai t-hitung sebesar 3,432451 sehingga diperoleh hasil t-hitung > t-tabel yaitu sebesar 3,432451 > 1,796 dengan nilai probabilitas sebesar 0,0056 < taraf signifikansi yang digunakan yaitu 0,05 maka dapat disimpulkan bahwa Ho ditolak dan Ha diterima atau dapat diartikan bahwa variabel kurs mempunyai pengaruh positif dan signifikan terhadap variabel cadangan devisa.

\section{Uji Signifikan Simultan (Uji F)}

Tabel 4.7 Hasil Perhitungan Uji F

\begin{tabular}{ll}
\hline \hline F-statistic & 38.73010 \\
Prob (F-statistic) & 0.000004 \\
\hline \hline
\end{tabular}

Sumber : E-Views 10, 2019 (Data Diolah)

Dari tabel 4.7 diperoleh nilai F-hitung sebesar 38,73010 sehingga diperoleh F-hitung > F-tabel yaitu sebesar 38,73010 > 3,48 dengan nilai probabilitas sebesar 0,000004 < taraf signifikansi yang digunakan yaitu 0,05 maka dapat disimpulkan bahwa Ho ditolak dan Ha diterima atau dapat diartikan bahwa variabel independen yaitu ekspor, impor dan kurs secara bersama-sama mempengaruhi cadangan devisa.

\section{Pembahasan}

\section{Pengaruh Ekspor Terhadap Cadangan Devisa Indonesia Tahun 2004 - 2018.}

Berdasarkan penelitian ini menghasilkan variabel ekspor memiliki pengaruh positif dan signifikan terhadap variabel cadangan devisa Indonesia. Hal ini dapat terjadi karena dengan melakukan kegiatan ekspor maka suatu negara akan memperoleh sejumlah uang sebagai pembayaran dalam bentuk valuta asing yang mampu menambah cadangan devisa. Salah satunya dapat ditunjukkan melalui nilai ekspor yang paling tinggi terjadi pada 2011 sebesar US\$ 203.496 juta sehingga juga mampu meningkatkan cadangan devisa sebesar $15 \%$ dari tahun sebelumnya menjadi US\$110.123 juta. Hasil penelitian ini sejalan dengan penelitian terdahulu yang dilakukan oleh Jimmy Beny (2013) yang hasilnya menunjukkan bahwa ekspor berpengaruh positif dan signifikan terhadap cadangan devisa.

\section{Pengaruh Impor Terhadap Cadangan Devisa Indonesia Tahun 2004 - 2018.}

Berdasarkan penelitian ini menghasilkan variabel impor memiliki pengaruh positif namun tidak signifikan pada variabel cadangan devisa. Hal tersebut salah satunya dapat dilihat dari impor barang mewah khususnya kendaraan bermotor seperti mobil mewah buatan luar negeri yang menjadi penyumbang pajak cukup besar bagi negara. Sesuai dengan Peraturan Menteri Keuangan (2018) mengenai tarif pajak impor barang mewah (PPnBM) sebesar $10 \%$ $125 \%$. Sehingga total biaya pajak impor barang mewah untuk 1 unit mobil mewah dapat mencapai $200 \%$. Dengan biaya pajak impor barang mewah yang dibayarkan oleh importir maka akan menambah cadangan devisa.

Dengan nilai impor yang tinggi maka pendapatan biaya pajak impor barang mewah juga tinggi sehingga akan menambah cadangan devisa. Namun hal tersebut akan mampu menyebabkan nilai rupiah semakin terdepresiasi. Sehingga pemerintah menerapkan kebijakan dengan meninggikan pajak impor barang mewah guna untuk membatasi kegiatan tersebut.

Selain itu, diperoleh hasil pengujian yang tidak signifikan artinya peningkatan impor juga dipicu oleh kuatnya permintaan dalam negeri akan barang impor tersebut, seperti barang mewah, barang konsumsi dan barang komoditas yang diikuti dengan harga bahan baku di Indonesia yang lebih murah dan biaya tenaga kerja yang juga murah. Sehingga menarik investor untuk melakukan penanaman modal di Indonesia dengan membangun pabrik akan barang yang 
selalu diimpor. Indonesia juga melakukan kegiatan utang luar negeri dan ekspor yang terus meningkat sehingga mampu menutupi biaya impor yang tinggi. Hasil penelitian ini sejalan dengan peneliian yang dilakukan oleh Agustina dan Reny (2014) bahwa pengaruh impor terhadap cadangan devisa yaitu positif dan tidak signifikan yang berarti variabel impor tidak berpengaruh terhadap cadangan devisa.

\section{Pengaruh Kurs Terhadap Cadangan Devisa Indonesia Tahun 2004 - 2018.}

Berdasarkan penelitian ini menghasilkan variabel kurs memiliki pengaruh positif dan signifikan pada variabel cadangan devisa. Hal ini dapat terjadi karena kebiasaan Indonesia yang melakukan kegiatan utang luar negeri sehingga tidak lepas dari ketergantungan ekonomi atas pembiayaan dari luar negeri. Dengan meningkatnya kurs yang diimbangi dengan meningkatnya utang luar negeri, maka dapat membuat cadangan devisa Indonesia naik karena utang luar negeri diterima dalam bentuk valuta asing

Besarnya utang luar negeri tersebut dialokasikan ke sektor produktif, utamanya untuk pembangunan infrastruktur. Sehingga dengan meningkatnya kurs maka nilai utang luar negeri Indonesia juga akan meningkat. Dengan semakin banyak valuta asing (valas) yang dimiliki oleh suatu negara berarti semakin besar pula kemampuan negara tersebut dalam melakukan transaksi ekonomi internasional.

Dengan itu maka kegiatan peminjaman utang luar negeri yang dilakukan oleh suatu negara akan berdampak pada cadangan devisa yang meningkat. Namun akan sangat merugikan dampaknya saat pembayaran pelunasan utang luar negeri. Dengan semakin meningkatnya kurs akan berdampak pada nilai rupiah yang terdepresiasi sehingga jumlah utang luar negeri yang harus dibayar semakin membengkak. Hasil penelitian ini sejalan dengan peneliian yang dilakukan oleh I Putu Kusuma Juniantara dan Made Kembar Sri Budhi (2011) yang menyatakan bahwa kurs berpengaruh positif dan signifikan terhadap cadangan devisa.

\section{KESIMPULAN DAN IMPLIKASI \\ Kesimpulan}

Variabel independen (X1) yaitu ekspor mempunyai pengaruh yang positif dan signifikan terhadap variabel dependen yaitu cadangan devisa Indonesia tahun 2004 - 2018. Variabel independen (X2) yaitu impor dikatakan tidak berpengauh terhadap variabel dependen yaitu cadangan devisa Indonesia tahun 2004 - 2018. Variabel independen (X3) yaitu kurs mempunyai pengaruh yang positif dan signifikan terhadap variabel dependen yaitu cadangan devisa Indonesia tahun 2004 - 2018. Variabel independen yaitu ekspor, impor dan kurs secara bersamasama atau simultan berpengaruh dan signifikan terhadap variabel dependen yaitu cadangan devisa Indonesia tahun 2004 - 2018.

\section{Implikasi}

Pemerintah melalui Kementerian Perdagangan sebaiknya lebih mengoptimalkan ekspor dan juga memberikan kemudahan dalam kebijakan struktural seperti perizinan yang akan menguntungkan eksportir. Dengan begitu maka cadangan devisa akan meningkat. Pemerintah melalui Kementerian Perdagangan melaksanakan kebijakan pembatasan Impor, baik dengan memperketat kebijakan tentang kegiatan impor seperti, mengurangi kuota impor, mengurangi impor produk-produk bermerek, menaikkan tarif impor dan tidak melakukan impor pada komoditas yang diproduksi di dalam negeri. Dengan menurunnya impor maka akan mampu menjaga cadangan devisa agar tetap aman. Variabel penelitian ini menitikberatkan pada variabel fiskal sehingga diperlukan penelitian berikutnya yang meneliti mengenai analisis yang mempengaruhi cadangan devisa dari sisi moneter sebagai dasar strategi alternatif bagi kebijakan moneter dalam mengendalikan nilai tukar rupiah. Karena dengan nilai tukar rupiah yang 
terkendali maka menandakan bahwa perekonomian negara baik dan cadangan devisa berada pada posisi yang aman.

\section{DAFTAR PUSTAKA}

Badan Pusat Statistik. (2017). Publikasi Statistik Indonesia 2017. Jakarta: BPS.

Badan Pusat Statistik. (2019). Publikasi Ekspor Indonesia. Jakarta: BPS.

Badan Pusat Statistik. (2019). Publikasi Impor Indonesia. Jakarta: BPS.

Badan Pusat Statistik. (2019). Publikasi Kurs Tengah Beberapa Mata Uang Asing Terhadap Rupiah. Jakarta: BPS.

Badan Pusat Statistik. (2019). Publikasi Posisi Cadangan Devisa. Jakarta: BPS.

Bank Indonesia. (2019). Publikasi Laporan Perekonomian Indonesia. Jakarta: Bank Indonesia.

Benny, J. (2013). Ekspor dan Impor Pengaruhnya Terhadap Posisi Cadangan Devisa di Indonesia. Jurnal Fakultas Ekonomi dan Bisnis Universitas Sam Ratulangi, 1406-1415.

Gandhi, D. V. (2006). Pengelolaan Cadangan Devisa di Bank Indonesia. Seri Kebanksentralan No. 17. Jakarta: Bank Indonesia.

Gujarati, D. N. (2015). Dasar-Dasar Ekonometrika. Jakarta: Salemba Empat.

Juniantara, I. P. (2011). Pengaruh Ekspor, Impor dan Kurs Terhadap Cadangan Devisa Nasional Periode 1999 - 2010. Jurnal Fakultas Ekonomi Universitas Udayana, 32-38.

Kuswantoro, M. (2017). Analisis Pengaruh Inflasi, Kurs, Utang Luar Negeri dan Ekspor Terhadap Cadangan Devisa Indonesia. Jurnal Universitas Sultan Ageng Tirtayasa, 146-168.

Mankiw, N. G. (2003). Teori Makroekonomi. Jakarta: Erlangga.

Manurung, A. H. (2016). Cadangan Devisa dan Kurs Valuta Asing. Jakarta: Kompas Media Nusantara.

Peraturan Menteri Keuangan Republik Indonesia Nomor 110 Tahun 2018 tentang Pemungutan Pajak Penghasilan Pasal 22 Sehubungan Dengan Pembayaran Atas Penyerahan Barang dan Kegiatan di Bidang Impor Atau Kegiatan Usaha di Bidang Lain. (2018).

Pundy Sayoga, S. T. (2017). Analisa Cadangan Devisa Indonesia dan Faktor - Faktor yang Mempengaruhinya. Jurnal Fakultas Ekonomi dan Bisnis Universitas Jambi, 25-30.

Putri, H. E. (2017). Pengaruh Ekspor, Penanaman Modal Asing dan Utang Luar Negeri Terhadap Cadangan Devisa di Indonesia. Jurnal Fakultas Ekonomi Universitas Riau, 240-252.

Reny, A. d. (2014). Pengaruh Ekspor, Impor, Nilai Tukar Rupiah dan Tingkat Inflasi Terhadap Cadangan Devisa Indonesia. Jurnal Program Studi Akuntansi STIE Mikeoskil, 61-70.

Simorangkir, I. d. (2004). Sistem dan Kebijakan Nilai Tukar Seri Kebanksentralan No. 10. Jakarta: Bank Indonesia.

Sukirno, S. (2013). Makro Ekonomi Teori Pengantar. Jakarta: Raja Grafindo Perkas.

Swara, D. A. (2018). Pengaruh Neto, Kurs, PDB dan Utang Luar Negeri Terhadap Cadangan Devisa Indonesia 1977-2016. E-Jurnal Ekonomi Pembangunan Universitas Udayana, 1199-1227.

Wibowo Tri, d. H. (2005). Faktor-Faktor Yang Mempengaruhi Nilai Tukar Rupiah. Jurnal Kajian Ekonomi dan Keuangan : Departemen Keuangan, 1-27. 